\title{
The Effectiveness of the Cooperative Learning Model of Jigsaw Type on the Results of Students Learned from Skills Critical Thinking of Vocational Schools
}

\author{
Ansheila Rusyda Subiyantari ${ }^{1}$, Supari Muslim² \\ ${ }^{1}$ Postgraduate Students of Surabaya State University \\ ${ }^{2}$ Professor of the Graduate Surabaya State University
}

Keywords: Jigsaw type cooperative learning model, critical thinking skills, learning outcomes, and vocational students.

Abstract: The quality of education in Indonesia needs to be continuously improved, especially Vocational High School (SMK). One way to improve the quality of education is through improving the quality of learning. In connection with this, several questions arise as follows: (1) what is meant by the jigsaw type cooperative learning model?; (2) what are the advantages of the jigsaw type cooperative learning model compared to other learning models?; (3) what is the effect of applying the jigsaw type cooperative learning model to students' critical thinking skills?; (4) what is the effect of applying the jigsaw type cooperative learning model to the learning outcomes of vocational students? Therefore, the objectives of this study are: (1) to know the jigsaw cooperative learning model; (2) to know the advantages of the jigsaw type cooperative learning model compared to conventional learning models; (3) analyze the effect of applying the jigsaw type cooperative learning model to students' critical thinking skills; (4) analyze the effect of applying the jigsaw type cooperative learning model to the learning outcomes of SMK students. This study uses literature review methods sourced from books and articles that are relevant to the topic. From a study of various literature it can be concluded that: (1) the jigsaw cooperative learning model is one of the cooperative learning models that emphasizes learning by constructing one's own knowledge by asking each other questions and discussing with group friends; (2) the advantages of the jigsaw type cooperative learning model compared to other learning models is that the learning model that is more student-centered, trains students to be responsible for the material that is part of it and to teach one another to their group mates; and (3) the application of the jigsaw type cooperative learning model is effective in training students' critical thinking skills; (4) the application of the jigsaw type cooperative learning model is effective for improving student learning outcomes, both learning outcomes in the cognitive, affective, and psychomotor domains.

\section{INTRODUCTION}

Education is an important means of improving human resources (Astuti, 2007). The quality of good education will produce good quality human resources, both in terms of spiritual, intelligence, and skill. Improving quality in the field of science and technology is growing more rapidly, therefore education must follow the development of science and technology, including improving the quality of Vocational High Schools. This is in accordance with the Presidential Instruction number 9 of 2016 concerning the revitalization of vocational education.
Revitalization of vocational education can be done among others through improving the quality of learning. Therefore the teacher as a facilitator must always be ready to serve the learning needs of students by creating pleasant learning situations, so as to encourage motivation and interest in student learning (Ekasari et al., 2018). Facts in the field show that teachers often only use a learning model that takes place in one direction, so students tend to be passive and less independent in gaining knowledge. Teachers are required to be able to apply fun learning models, students are more motivated to learn, more responsible for their learning, and their learning 
the assessment determines the score obtained in the

achievement increases. One of the learning models is the Jigsaw cooperative learning model

Based on the introduction as described above, the problem is formulated as follows: (1) what is meant by the jigsaw cooperative learning model? (2) what are the advantages and disadvantages of the jigsaw type cooperative learning model compared to other learning models?; and (3) what is the effect of applying the jigsaw type cooperative learning model to students' critical thinking skills?; (4) what is the effect of applying the jigsaw type cooperative learning model to the learning outcomes of vocational students?

\section{THEORITICAL REVIEW}

\subsection{Jigsaw Cooperative Learning Model}

The jigsaw type cooperative learning model was developed by Elliot Aronson and friends who later developed by Slavin. This learning model divides knowledge from books or chapters into smaller ones that are more manageable (Garcia et al., 2017). In the Jigsaw method students are grouped twice, namely when with their own groups and in expert groups (Huda, 2013). The advantages of the jigsaw type cooperative learning model of students can depend on both the expert group and the original group to achieve success in learning (Lai \& Wu, 2006).

The purpose of the cooperative learning model can encourage students to think higher (Lee, 1997) . In line with this, the jigsaw cooperative learning model also makes students have greater responsibility in implementing learning (Suendarti, 2017). The use of the right learning model can make students more creative (Suendarti, 2017) because learning does not only emphasize mastery of knowledge, but also emphasizes internalization of what is learned.

\subsection{The Jigsaw Type Cooperative Learning Syntax}

The syntax of the jigsaw type cooperative learning model according to Slavin (2005) is as follows: (1) students are divided into several groups, each group 4-5 members who are heterogeneous; (2) students are given different topics and assignments; (3) students who have the same topic gather in expert groups to discuss topics and assignments given by the teacher; (4) each student from the expert group returns to their original group to take turns teaching his group mates on their topic; (5) students are given exercises that cover the whole individually by the teacher; (6) students obtain an assessment from the teacher and group; (7) the teacher gives awards to the group that gets the highest score, then gives reinforcement of the subject matter to the students.

\subsection{Strengths and Weaknesses of the Jigsaw Cooperative Learning Model}

The jigsaw cooperative learning model has various advantages including the following: (1) facilitating the work of the teacher in teaching because there is already a group of experts tasked with explaining the material to his colleagues; (2) increasing motivation in learning and the sense of responsibility of learning by students towards themselves and others; (3) even distribution of material mastery can be achieved in a shorter time; (4) train students to be more active in speaking and arguing; (5) weak students can be helped in solving problems by being helped by students who better understand the material; (6) deeper understanding of the material because it applies the guidance of fellow friends. Students will be more easily understood if guided by people of the same age; (7) in the learning process students are positively interdependent; (8) provide opportunities for students to cooperate with other groups; (9) each student fills one another.

The disadvantages of this type of jigsaw cooperative learning are as follows: (1) more active students will dominate the discussion and tend to control the course of the discussion. To anticipate this problem the teacher must really pay attention to the course of the discussion. The teacher must emphasize so that the group members listen first to the explanation of the experts. Then just ask questions if you don't understand; (2) students who have low reading and thinking skills will find it difficult to explain the material if they are appointed as experts. To anticipate this, the teacher must select experts appropriately, then monitor their performance in explaining the material, so that the material can be conveyed accurately; (3) smart students tend to feel bored; (4) students who are not accustomed to competing will find it difficult to follow the learning process; (5) requires a longer time, especially if there is no well-conditioned spatial planning, so it is necessary to change positions which can also cause noise and time and preparation.

\subsection{Critical Thinking Skills}

The application of process skills must be carried out by the teacher in the learning process which previously considered and paid attention to the 
characteristics of students and also the characteristics of the subjects (Dimyati \& Mudjiono, 2010). The process of thinking without any critical elements will tend to be biased, chaotic, not intact, and lead to prejudice based not on information (Tuanakota, 2011).

Furthermore, according to (Amri, 2013) the stages of thinking at a high level are called critical thinking. Critical thinking uses a basic thought process to analyze arguments and produce insights into certain meanings and interpretations (Lee, 1997). Critical thinking does not mean attacking or overthrowing others, but the ability to reason rationally so as to find a view (Sihotang et al., 2012). In a learning process students can develop various skills, one of which is critical thinking skills. Critical thinking skills are rational and reflective thinking that is focused on what is believed and done (Ennis, 1996). Rational means having confidence and views that are supported by actual and relevant evidence, while reflective is to consider actively and carefully all alternatives before making a decision.

\subsection{Learning Outcomes}

The jigsaw cooperative learning model is expected to be able to influence the increase in student learning outcomes. Learning is an interaction that occurs between the internal state of students and cognitive processes of students with stimuli from the environment (Dimyati \& Mudjiono, 2010). Changes in behavior caused by the learning process make students have mastery of the subject matter delivered by the teacher to achieve learning goals. Learning outcomes are changes in human behavior resulting from learning and can be in the form of learning impacts or accompaniment impacts. This is a peak in the learning process.

In Aunurrahman's book (2016) learning outcomes consist of three domains, namely the cognitive domain (Bloom, et al) which consists of six levels of behavior, affective domain (Krathwohl, Bloom, et al) which consist of five types of behavior, and psychomotor domains (Simpson) which consists of seven behaviors.

The cognitive learning outcomes consist of six levels of behavior (Anderson \& Krathwohl, 2001), namely: (1) remembering, including the ability to remember things that have been learned and which are stored in memory. Knowledge regarding facts, events, understanding, rules, theories, principles, or methods; (2) understand, includes the ability to capture the meanings of things that have been learned; (3) implement, including the ability to apply methods to deal with real or new problems; (4) analyze, including the ability to specify a unit into parts so that the overall structure can be well understood; (5) evaluating, including the ability to form opinions and assess based on certain criteria; (6) creating, including the ability to create planning or design in performance.

Affective domain according to Bloom, Krathwohl, \& Masia (1973) consists of five types of behavior, namely: (1) acceptance, including sensitivity and attention to something; (2) participation responds, including the willingness to pay attention and participate in an activity; (3) assessment, including acceptance of a value, respecting, acknowledging, and determining attitudes; (4) organization, including the ability to form a value as a life guide; and (5) the formation of values, including the ability to live up to values and shape them into a pattern of values in personal life.

Psychomotor learning outcomes according to Dave (Muslim, 2013) consist of five levels, namely: (1) imitation, students can carry out activities by imitating what has been seen; (2) manipulation, students can carry out certain activities on the basis of instructions or orders; (3) precision, students are able to carry out activities that are of a precision nature, which includes elements of accuracy, accuracy, and balance even though these activities have not yet been seen as a whole; (4) articulation, students are able to coordinate a series of activities that are precision in order and appropriate; (5) naturalization, students are able to do activities that are naturally sequential and carried out with minimum energy.

\section{METHOD}

This research was conducted with a literature review of references and relevant research results. References is among the books and journals about learning model. While the study of the results of relevant research is a study of the results of research related to the jigsaw type cooperative learning model in Vocational High School.

\section{RESULTS AND DISCUSSION}

As explained in the theoretical study, the jigsaw type cooperative learning model has many advantages that can influence students' critical thinking skills and on student learning outcomes. Several research studies related to the jigsaw cooperative learning model, namely research from Ariyanti, Lasmawan, \& Dantes (2013) which states that the jigsaw cooperative learning model helps students to think critically in solving problems 
encountered during learning. In the jigsaw cooperative learning model, students are often trained in exchanging ideas, arguing, exchanging information, and solving problems in discussion groups so that students develop skills to be more critical and able to solve more complex problems. This learning model also builds social relationships between students so that students feel learning in a comfortable and family atmosphere.

Cooperative learning models develop an interaction that trains each other to educate and tolerate attitudes between students as life training in community life. Finding solutions to problem solving will be more effective if done in collaboration and in groups. Heterogeneous division of students in groups makes it easy for students to interact with each other. Interactions and students 'ability to work together are influenced by internal factors such as students' skills in critical thinking.

The jigsaw cooperative learning model makes learning more interesting, fun, and enlightening because it brings a lot of things to the mind (Ariyanti et al., 2013). This makes students motivated in discussing subject matter and able to think deeply, independently, and analyze critically. In line with the results of these studies, Zahara (2012) in his research entitled "Physics learning through STAD and jigsaw II types and student personality orientation" that there were differences in student learning achievement in the jigsaw type learning model.

This is reinforced by the results of research that show that by using the jigsaw cooperative learning model students show critical thinking skills better than conventional learning models (Nur \& Abdullah, 2014) and the jigsaw cooperative learning model combined with PBL further enhances thinking skills student (Palennari, 2012).

Critical thinking is an intellectual process that actively and skillfully conceptualizes, implements, analyzes, synthesizes, and evaluates information collected resulting from observation, experience, reflection, reasoning, or communication in underlying an action. In the research of Wati \& Anggraini (2019) explained that learning in the classroom is better by using the jigsaw cooperative learning model compared to using conventional learning models. This is because the jigsaw cooperative learning model teaches students to find the truth of the problem independently by forming groups of origin and expert groups.

Several research studies related to the application of the jigsaw type cooperative learning model, namely research from Basyah \& Muslem (2017) which found that the jigsaw type cooperative learning model shows significant positive changes in learning outcomes and student learning styles compared to conventional learning models. Yemi, et al (2018) also found that student achievement of the experimental group which studied the Jigsaw type learning model is better than the students who learn by lecture method because it can help students in solving problems.

In line with the results of the study, Ardiyanto, Santosa, \& Sudiyanto (2013) conducted a study entitled "Effectiveness of the application of the Jigsaw type cooperative model to the learning achievement of accounting subjects of students in 2 Karanganyar Public High School 2011/2012 academic year" that type cooperative learning jigsaw is more effective than conventional learning on student achievement. Other research conducted at Vocational High School by Ifa (2013); and Mawinda, Naansah, \& Hanesman (2014), showed that student learning outcomes using the jigsaw type cooperative learning model were higher than the learning outcomes of students who used the direct learning model.

The same study was conducted by Ritonga \& Ruslan (2017) who found that: (1) students who were taught with a jigsaw type cooperative learning model had improved learning outcomes; (2) learning outcomes of students who study with the jigsaw type cooperative learning model, higher than conventional learning models.

Besides being able to improve learning outcomes, several studies related to the jigsaw type cooperative learning model as done by Yasri (2017), that the application of the jigsaw type cooperative learning model can increase student activity during the learning process, which is characterized by an increase in the activeness of students in asking and answering at 2 Walenrang Vocational High School. In addition, the application of a jigsaw type cooperative learning model can improve student learning outcomes.

In line with these findings, Azmin (2015) conducted a study entitled "Effect of the jigsaw-based cooperative learning method on advanced-level psychology certificate: an exploratory Brunei case study" which showed that there was an increase in understanding and student performance, which leads to improved student learning outcomes, after the implementation of the Jigsaw type cooperative learning model.

The application of the jigsaw type cooperative learning model is more conducive, neat, students are more active and compact in the learning process than in the conventional learning process which tends to 
knowledge by asking each other questions and

be monotonous and teacher-centered (Muhanif \& Yunus, 2017). The application of the Jigsaw type cooperative learning model can train students to develop ideas compared to conventional learning models (Kaka, 2016). Rachmah (2017) added that the application of the Jigsaw type cooperative learning model could improve self-efficacy, student motivation, increasing knowledge, and competence of students in the scope of small and large classrooms.

In addition, the results of several relevant studies conclude that in addition to the use of the jigsaw type cooperative learning model can improve problem solving skills (Suendarti, 2017), it is effective to help deliver material in the classroom compared to conventional learning models (Rinawan \& Krismiyati, 2014), and can develop students' soft skills, and be effective in developing thinking skills at analyze, evaluate and create levels of Bloom's taxonomy (Dhage, et al., 2016).

This is supported by the research of Jafariyan, Matlabi, Esmaeili, \& Kianmehr (2017) entitled "Effectiveness of teaching: jigsaw technique vs. lecture for medical students' physics course" which found that jigsaw cooperative learning can be used as one of the more learning approaches effective, because it can improve the learning experience, encourage interest in learning, and create interaction and cooperation between teachers and students.

The jigsaw type cooperative learning model is a good example to be applied in order to encourage team work, communication, critical thinking, and lifelong learning (Buhr et al., 2014) especially for vocational students. The jigsaw cooperative learning model supports the development of problem solving in students because students learn with smaller groups that are more specific (Buhr et al., 2014).

Based on some relevant research results related to the application of the jigsaw type cooperative learning model for junior high school and vocational students, the jigsaw cooperative learning model is rightly used as an alternative to improve the learning outcomes of Vocational students through increasing student activity, independence and thinking skills in managing knowledge and his own experience.

\section{CONCLUSIONS}

Based on studies of various literature and relevant research results as described above, it can be concluded that:

1. The jigsaw cooperative learning model is one of the cooperative learning models that emphasizes students to learn by constructing their own discussing with group friends. In the jigsaw type cooperative learning model, students group for two times, namely when grouping with expert groups and grouping with their own groups.

2. The advantages of the jigsaw type cooperative learning model compared to other learning models is that this learning model trains the activeness of students in the learning process, learning is more student-centered, not more to the teacher. Jigsaw cooperative learning model train students to be responsible for the material that is part of the group of experts, to teach each other to fellow friends in one group.

3. The application of the jigsaw type cooperative learning model can create a class atmosphere that is more interesting, fun, and enlightening because it brings a lot of things to the mind so that they can train students' critical thinking skills.

4. The jigsaw cooperative learning model improves students 'ability to solve problems, student activity, student performance, student selfefficacy, and students' understanding that positively influences their learning outcomes. In addition, the jigsaw cooperative learning model help students get their own learning experience, encourage student interest and motivation, and create collaboration between teachers and students. Implementation of the jigsaw type cooperative learning model also helps teachers in delivering learning material in the classroom. 


\section{REFERENCES}

Anderson, L., \& Krathwohl, D. (2001). A taxonomy for learning, teaching, and assessing (a revision of Bloom's taxonomy of educational objectives. New York: Longman Group Ltd.

Ariyanti, N. W., Lasmawan, I. W., \& Dantes, N. (2013). Pengaruh model pembelajaran kooperatif tipe jigsaw terhadap kemampuan berpikir kritis dan prestasi belajar siswa dalam pembelajaran IPS pada siswa kelas IV SD Cipta Dharma Denpasar. E-Journal Program Pascasarjana Universitas Pendidikan Ganesha, 3, 2-10.

Astuti, B. (2007). Pengembangan SDM menuju pendidikan berkualitas.

Aunurrahman. (2016). Belajar dan pembelajaran. Bandung: Alfabeta.

Azmin, N. H. (2015). Effect of the jigsaw-based cooperative learning method on student performance in the general certificate of education advanced-level psychology: an exploratory Brunei case study. International Education Studies, 9, 91-106.

Basyah, N. A., \& Muslem, A. (2017). The effectiveness of using the jigsaw model to improve students' economics teaching-learning achievement. New Educational Review, 50, 26-35.

Bloom, B., Krathwohl, D., \& Masia, B. (1973). Taxonomy of educational objectives (book 2 affective domain). London: Longman Group Ltd.

Buhr, G. T., Heflin, M. T., White, H. K., \& Pinheiro, S. O. (2014). Using the jigsaw cooperative learning method to teach medical students about long-term and postacute care. Journal of the American Medical Directors Association, 15, 429-434.

Dhage, P. J. R., Pawar, P. A. B., \& Patil, M. S. (2016). Effect of the jigsaw-based cooperative learning method on engineering students. National Conference NCIEME, 1-7.

Dimyati, \& Mudjiono. (2010). Belajar dan pembelajaran. Jakarta: Rineka Cipta.

Ekasari, R. R., Gunawan, \& Sahidu, H. (2018). Pengaruh model pembelajaran langsung berbantuan media laboratorium terhadap kreatifitas fisika siswa SMA. Jurnal Pendidikan Fisika dan Teknologi, II, 106-110.

Garcia, B. A., Ed, D., Abrego, J., Ed, D., \& Robert, R. (2017). Using the jigsaw method for meaningful learning to enhance learning and rentention in an educational leadership graduate school course. Global Journal of Human-Social Science: G Linguistics \& Education, 17, 1-13.

Huda, M. (2013). Cooperative learning. Yogyakarta: Pustaka Pelajar.

Ifa, M. (2013). Penerapan model pembelajaran kooperatif tipe jigsaw untuk meningkatkan hasil belajar siswa kelas X SMK Negeri 3 Boyolangu pada standar kompetensi menerapkan keselamatan dan kesehatan kerja (k3). Jurnal Pendidikan Teknik Elektro, 2, 715-722.

Jafariyan, M., Matlabi, M., Esmaeili, R., \& Kianmehr, M. (2017). Effectiveness of teaching: jigsaw technique vs lecture for medical students' physics course. Bali Medical Journal, 6, 529-533.

Kaka, P. (2016). Pengaruh model pembelajaran kooperatif jigsaw dan konsep diri akademik terhadap kemampuan berbahasa Indonesia siswa SMP. Jurnal Ilmiah Pendidikan Citra Bakti, 4, 65-76.

Lai, C. Y., \& Wu, C. C. (2006). Using handhelds in a jigsaw cooperative learning environment. Journal of Computer Assisted Learning, 22, 284-297.

Lee, C. (1997). Cooperative learning in the thinking classroom: research and theoretical perspectives. Eric, 1-22.

Mawinda, N., Naansah, Z., \& Hanesman. (2014). Pengaruh model pembelajaran kooperatif tipe jigsaw terhadap hasil belajar siswa pada mata pelajaran dasar kelistrikan dan elektronika kelas X TAV di SMKN 1 Padang. Jurnal Vokasional Teknik Elektronika \& Informatika, 2, 1-5.

Muhanif, \& Yunus. (2017). Penerapan model pembelajaran kooperatif tipe jigsaw untuk meningkatkan hasil belajar siswa pada mata pelajaran teknologi mekanik kelas X TPM SMK Negeri 5 Surabaya. JPTM, 6, 131 -138.

Muslim, S. (2013). Tes kinerja (performance test) dalam bidang Pendidikan Teknologi dan Kejuruan. Paper presented at Seminar Nasional Teknik Elektro dan Pendidikan Teknik Elektro, 1-26.

Nur, I. M., \& Abdullah, I. H. (2014). Penggunaan model pembelajaran kooperatif tipe jigsaw untuk meningkatkan kemampuan berpikir kritis dan soft skill matematis siswa SMA. Jurnal Matematika Dan Pendidikan Matematika, 3, 39-53.

Palennari, M. (2012). Potensi integrasi problem based learning dengan pembelajaran kooperatif jigsaw dalam meningkatkanketerampilan berpikir kritis mahasiswa. Jurnal Bionature, 13, 1-9.

Rachmah, D. N. (2017). Effects of jigsaw learning method on students' self-efficacy and motivation to learn. Journal of Educational, Health and Community Psychology, 6, 1-9.

Rinawan, S. Y., \& Krismiyati. (2014). Efektivitas penggunaan metode pembelajaran jigsaw berbasis wifi ad hoc dalam pembelajaran sistem basis data kelas XI jurusan rekayasa perangkat lunak (studi kasus SMKN 1 Tengaran). Jurnal Teknologi Informasi-Aiti, 11, 101-202.

Ritonga, M., \& Ruslan, D. (2017). The effect of jigsaw learning strategy to students ' civic learning outcomes in grade V SDN 107403 Cinta Rakyat academic year 2016/2017. IOSR Journal of Research \& Method in Education, 7, 64-72.

Sihotang, K., Rima K., F., Molan, B., Ujan, A. A., \& Ristyantoro, R. (2012). Critical thinking membangun pemikiran logis. Jakarta: Pustaka Sinar Harapan.

Slavin, R. (2005). Cooperative learning (Zubaedi, Ed.). Bandung: Nusa Media.

Suendarti, M. (2017). The influence of jigsaw learning model on the ability of resolution natural science of Middle East Junior High School students Indonesia. International Journal of Environmental \& Science 
pertanian SMK Negeri 2 Walenrang). Jurnal Pendidikan Teknologi Pertanian, 3, 1-14.

Yemi, T. M., Binti, N., \& Azid, H. (2018). Effect of jigsaw strategy of cooperative learning on mathematics achievement among secondary school students. European Journal of Education Studies, 4, $51-61$.

Zahara, L. (2012). Pembelajaran fisika melalui tipe STAD dan jigsaw II dan orientasi kepribadian siswa. Jurnal Education, 7, 75-91. 